\title{
From South Florida to South Africa: A Collaborative Approach for Making Science Sensible to Learners in Informal and Formal Settings
}

\author{
Anthony Lelliott ${ }^{1, *}$, Tiffany Plantan ${ }^{2} \&$ Michael Gaines $^{2}$ \\ ${ }^{1}$ Marang Centre for Maths and Science Education, University of the Witwatersrand, \\ Johannesburg, South Africa \\ ${ }^{2}$ Cox Science Center, Department of Biology, University of Miami, Florida, USA
}

*Corresponding author: Marang Centre for Maths and Science Education, Private Bag 3, University of the Witwatersrand, Wits 2050, Johannesburg, South Africa

Tel: +27 117173260 E-mail: Tony.Lelliott@wits.ac.za

Received: May 9, 2012 Accepted: August 27, 2012 Published: November 2, 2012

doi:10.5296/ije.v4i4.1788 URL: http://dx.doi.org/10.5296/ije.v4i4.1788

\begin{abstract}
This paper presents two innovative programs in the learning of science by schoolchildren and youth: Science Made Sensible (SMS) and Science Cafés (SC). In South Florida, the SMS program invites graduate students in science, technology, engineering and mathematics to pair with middle school science teachers over the course of an academic year and assist with the teaching of science in the classroom. The program has been extended internationally to South Africa, where the SMS graduate fellows and SMS teachers from South Florida collaborate with students and teachers in South African middle schools. The SC concept encourages working scientists to discuss science with young people in a resource-poor township environment. On a regular basis, different scientists are invited to dialogue and informally share their research with youth. The concept of science communication strategies is discussed to show that models which involve learning are as valuable in resource-poor environments as are the dialogue events becoming popular in developed countries. SMS and SC work in similar communities in and around Pretoria, South Africa, and complement each other. Evaluations of both programs have been highly rated by participants and the model of partnership suggests that they are very valuable for the learning of science in underserved communities.
\end{abstract}

Keywords: formal learning; informal learning; science education; science café; underserved community 


\section{Introduction}

Science learning can be viewed as being formal and informal, whereby the former is institutionalized, structured and assessed within an education system while the latter is a lifelong non-assessed process in which knowledge and other attributes are accumulated from a variety of sources and experiences (Coombs \& Ahmed, 1974; Falk \& Dierking, 2000). In this paper we present the Science Made Sensible (SMS) program as an example of (mainly) formal learning, while Science Cafés (SC) exemplify informal education.

There is considerable evidence in middle school classrooms that teachers rely on curriculum materials to provide much of their science content knowledge (Kesidou \& Roseman, 2002). In addition to curriculum resources, the content knowledge of an actual scientist would be a welcome addition to the classes of most teachers. The SMS program provides just that: a scientist in the classroom. SMS, funded by the National Science Foundation (NSF), began in 2007 as a partnership between the University of Miami and Miami-Dade County Public Schools, both in Florida, USA. The SMS program pairs graduate student fellows in the science, technology, engineering, and mathematics (STEM) disciplines with local middle school science teachers. The aim of the program is to 1) improve the communication and teaching skills of graduate students, 2) enhance the professional development of middle school teachers, and 3) advance the scientific curiosity and learning of middle school students.

There is a worldwide concern that not enough schoolchildren and young adults are entering the STEM disciplines (Gallant, nd), and various programs have been developed to address this need. Although Café Scientifique (cafescientifique.org/) is concerned mainly with bringing the public and scientists together in a dialogue, it can be adapted to local contexts, as has been done in South Africa. Although there are a few scientist-public seminars in various venues around the country (such as at universities and science centers), the Science Café concept aims to engage young people with science in contexts where there traditionally has been little such engagement.

This paper provides an overview of the SMS and SC programs, and, using evaluations conducted over recent years, demonstrates how engaging school students and other youth directly with scientists can provide a platform for their development within the STEM disciplines.

\section{Literature Review}

As a mode of learning, informal education is usually contrasted with the terms 'formal' and 'non formal'. According to Falk (Falk \& Dierking, 2001) these terms, developed by researchers in international development, go back nearly 50 years and were later used by the museum community to distinguish between school-based learning and out-of-school activities. Hofstein and Rosenfeld (1996)prefer a 'hybrid' approach which allows that certain 'formal' aspects of learning can take place under informal conditions, but that informal learning is essentially an out-of-school, unstructured, voluntary activity. A related field is 
science communication which disseminates the processes and products of science to the general public. Whereas SMS falls under the auspices of formal learning about science, SCs are essentially part of informal science communication, being voluntary, out-of-school and relatively unstructured. Research into what are termed 'dialogue events' is in its infancy and is under-theorized (Trench, 2008). Recent studies indicate that forums such as SCs and SMS have the potential to act as sites of learning as scientists interact directly with audiences and in the classroom respectively (Lehr et al., 2007; McCallie et al., 2007).

\section{Science Made Sensible}

\subsection{Science Made Sensible in South Florida}

Since 1999, the NSF Graduate STEM Fellows in K-12 Education (GK-12) Program has funded over 200 projects in more than 140 different universities throughout the USA and Puerto Rico. SMS is one of these GK-12 projects. SMS graduate student fellows and science teachers work in pairs for one continuous academic year in 6th, 7th, or 8th grade science classrooms. They strive to make the science education experience interesting and exciting for middle school students.

Prior to the start of the school year, the SMS graduate fellows and teachers participate in a two-week summer institute at the University of Miami. Morning workshop sessions focus on how students learn through modules in oral and written communication, pedagogy, team building, and evaluation. During the afternoon workshop sessions, the fellows and teachers work together to analyze the Next Generation Sunshine State Standards for science and teaching materials for their respective grades. Graduate fellow and teacher teams integrate the graduate fellows' research into inquiry and research-based activities and lesson plans in the appropriate science curriculum unit. For the other units of the science curriculum, the fellows work with the teachers to incorporate quantitative activities and interdisciplinary approaches through problem-based learning.

During the school year, fellow/teacher pairs implement the lesson plans and activities developed during the summer institute. They also assist students with science fair projects and help them prepare for state standardized testing. For example, in a given class period, the SMS fellow/teacher team may introduce a science topic to the students by engaging them through the use of a PowerPoint lecture, educational video clip, Pixton comic strip, or a demonstration lab. Then to aid students in grasping the topic, the SMS team invites the students to participate in an inquiry-based lesson plan. To date, more than 100 original lesson plans that meet the Miami-Dade County Next Generation Sunshine State Standards have been created and disseminated through the SMS program (see examples at www.smsmiami.org). Another aspect of SMS is the annual development of a communal science project across participating SMS schools. Students from each school work together to collect data on a selected research topic. Students learn scientific skills, responsibility, cooperation, and collaboration. In 2008-2009 students designed experiments about solar energy and photosynthesis and dubbed this communal project "Here Comes the Sun". And in 2010-2011 
students created a communal project called "Dig It!" in which they designed experiments about Miami soil types and their effects on plant growth. Additionally, each graduate fellow incorporates his or her research into classroom activities. The students get most excited about this, for they are experiencing research by a "real scientist" first-hand. Furthermore, the use of web 2.0 technology has become integral to the SMS program. Wikispaces enable interaction outside the classroom and provide a place to review class material. Blogs and social media such as twitter are used for class discussions and facilitate interaction between teachers and students outside the classroom.

Program evaluations conducted using a Likert scale revealed that the SMS program has had a major impact on student, fellow, and teacher performance (Tables 1-3). Ninety percent of fellows agreed that after the program they were adequately prepared to explain their research to non-scientists. Eighty-five percent of teachers agreed that after participating in SMS they know science well enough to replace lecture presentations with labs on almost any subject in the middle school curriculum. More than $75 \%$ of students agreed that having a fellow in the classroom made science more sensible.

Table 1: Evaluation responses of students in the Miami Science Made Sensible program during the 2009-2010 and 2010-2011 academic years

\begin{tabular}{|c|c|c|c|}
\hline $\begin{array}{l}\text { During the past year, I really understood what was } \\
\text { taught in science class. }\end{array}$ & $\mathbf{N}=$ & Agree & Disagree \\
\hline $\begin{array}{l}\text { During the past year, I was happy with my science } \\
\text { grades. }\end{array}$ & 1252 & $\begin{array}{c}1127 \\
(90 \%)\end{array}$ & $\begin{array}{c}125 \\
(10 \%)\end{array}$ \\
\hline During the past year, we did lots of science labs. & 1238 & $\begin{array}{c}950 \\
(77 \%)\end{array}$ & $\begin{array}{c}288 \\
(23 \%)\end{array}$ \\
\hline $\begin{array}{l}\text { During the past year, I learned how to apply science } \\
\text { outside of school. }\end{array}$ & 1231 & $\begin{array}{l}1042 \\
(85 \%)\end{array}$ & $\begin{array}{c}189 \\
(15 \%)\end{array}$ \\
\hline $\begin{array}{l}\text { During the past year, I learned how to use math in order } \\
\text { to do science. }\end{array}$ & 1172 & $\begin{array}{c}936 \\
(80 \%)\end{array}$ & $\begin{array}{c}236 \\
(10 \%)\end{array}$ \\
\hline $\begin{array}{l}\text { Having a scientist in the classroom helped me } \\
\text { understand science. }\end{array}$ & 1187 & $\begin{array}{c}984 \\
(83 \%)\end{array}$ & $\begin{array}{c}203 \\
(17 \%)\end{array}$ \\
\hline $\begin{array}{l}\text { I would like a scientist to work in my future science } \\
\text { classes. }\end{array}$ & 1184 & $\begin{array}{c}909 \\
(77 \%)\end{array}$ & $\begin{array}{c}275 \\
(23 \%)\end{array}$ \\
\hline $\begin{array}{l}\text { During the past year, I really understood what was } \\
\text { taught in science class. }\end{array}$ & 1224 & $\begin{array}{l}1071 \\
(88 \%)\end{array}$ & $\begin{array}{c}153 \\
(12 \%)\end{array}$ \\
\hline
\end{tabular}


Table 2: Evaluation responses of graduate fellows in the Miami Science Made Sensible program during the2008-2009, 2009-2010, and 2010-2011 academic years

\begin{tabular}{llll}
\hline $\begin{array}{l}\text { I am adequately prepared to explain my research to } \\
\text { non-scientists. }\end{array}$ & $\mathbf{N}=$ & Agree & Disagree \\
\hline $\begin{array}{l}\text { I am adequately prepared to present basic ideas about } \\
\text { my field of study to the general public. }\end{array}$ & 40 & $36(90 \%)$ & $4(10 \%)$ \\
$\begin{array}{l}\text { I have a very good idea of what a science teacher's job } \\
\text { entails. }\end{array}$ & 40 & $35(87 \%)$ & $5(13 \%)$ \\
$\begin{array}{l}\text { The purpose of teaching science is to develop a } \\
\text { well-informed and broadly educated learner. }\end{array}$ & 37 & $32(86 \%)$ & $5(14 \%)$ \\
$\begin{array}{l}\text { People learn science best by participating in structured } \\
\text { lab work. }\end{array}$ & 41 & $38(93 \%)$ & $3(7 \%)$ \\
$\begin{array}{l}\text { I am adequately prepared to explain my research to } \\
\text { non-scientists. }\end{array}$ & 39 & $36(92 \%)$ & $3(8 \%)$ \\
\hline
\end{tabular}

Table 3: Evaluation responses of teachers in the Miami Science Made Sensible program during the2008-2009, 2009-2010, and 2010-2011 academic years

\begin{tabular}{lccc}
\hline & $\mathbf{N}=$ & Agree & Disagree \\
\hline $\begin{array}{l}\text { I know science well enough to lecture about it to middle } \\
\text { school students with few, if any, mistakes. }\end{array}$ & 27 & $26(96 \%)$ & $1(4 \%)$ \\
$\begin{array}{l}\text { I know science well enough to replace lecture } \\
\text { presentations with labs on almost anything in the middle } \\
\text { school curriculum. }\end{array}$ & 27 & $23(85 \%)$ & $4(5 \%)$ \\
$\begin{array}{l}\text { Middle school students learn science best through } \\
\text { structured lab work. }\end{array}$ & 27 & $25(93 \%)$ & $2(7 \%)$ \\
$\begin{array}{l}\text { My students came into my class well-prepared to learn } \\
\text { the science that I needed to teach them. }\end{array}$ & 27 & $7(26 \%)$ & $20(74 \%)$ \\
$\begin{array}{l}\text { My students are leaving my class well prepared for next } \\
\text { year's science course work. }\end{array}$ & 25 & $23(92 \%)$ & $2(8 \%)$ \\
\hline
\end{tabular}

\subsection{Science Made Sensible in South Africa}

Due to the success of our SMS program in Miami, we wanted to extend our program internationally. Our goal was to learn about South Africa's educational system, develop lesson plans in collaboration with South African middle school teachers, and share effective pedagogical techniques used in the classroom. We chose South Africa because of its environmental and social parallels with South Florida. The problems in many South African schools mirror the problems in Miami's inner-city schools. There are achievement gaps among learners from different ethnic groups and between those of different socio-economic status (Frempong, Reddy \& Kanjee, 2011; National Research Council, 2011). These problems, coupled with a lack of teacher expertise in the basic sciences and inadequate educational 
resources for underserved populations in the public schools of both countries, could eventually result in shortages of scientists, technologists, engineers, and mathematicians.

The goals of SMS in South Africa were three-fold. Firstly, it aimed to improve the communication skills of graduate student fellows which in turn enabled them to convey their research effectively. Secondly, it provided a "resident scientist" for middle school teachers in their classes - a substantial resource for the teachers to draw upon in the generally resource-poor environment of South African schools (Adler \& Reed, 2002). Thirdly, SMS aimed to expose middle school students to scientific research and original inquiry-based activities. The SMS visitors would interact with students in 6th and 7th grade science classrooms, collaborate with South African science teachers, and develop lesson plans to be incorporated into classrooms in both Miami and South Africa.

In spring 2009, we were awarded an international supplement grant to our NSF GK-12 SMS program. This supplement allowed us to involve select fellows and teachers in research and teaching activities in South Africa. Four SMS graduate fellows, two SMS Miami science teachers, and the SMS director piloted the international program. The team spent a week working with teachers and students at two middle schools in Pretoria. Participants were divided into teams, with each team consisting of two Miami graduate fellows, one Miami science teacher, and one South African science teacher. The international SMS teams collaborated to create and implement lesson plans that related to the science topics being taught in the classroom. For example, students used hardboiled eggs to learn about the layers of the earth and plate tectonics. As a result of the positive response to SMS in South Africa, we were awarded two successive supplement grants. In August 2010 and 2011, we expanded our program to include three middle schools and we lengthened the number of days spent in the schools. Students learned about thermal energy by working in groups to design their own solar cookers using a variety of provided materials. In another activity, students learned about volcanoes by building models and giving presentations to the class.

Following each year of SMS in South Africa, we evaluated the participating fellows and teachers using a Likert scale (Figure 1.). Generally, participants were very positive in their evaluations of the program. The Miami SMS fellows and teachers developed an appreciation for the common challenges of teaching in Miami and Pretoria $(100 \%$ agree/strongly agree; $n=16)$. All of the South African teacher participants $(n=15)$ agreed/strongly agreed that they could incorporate the SMS activities into their classrooms. The only negative comments were regarding the time for planning and interaction between the USA and South African participants. 


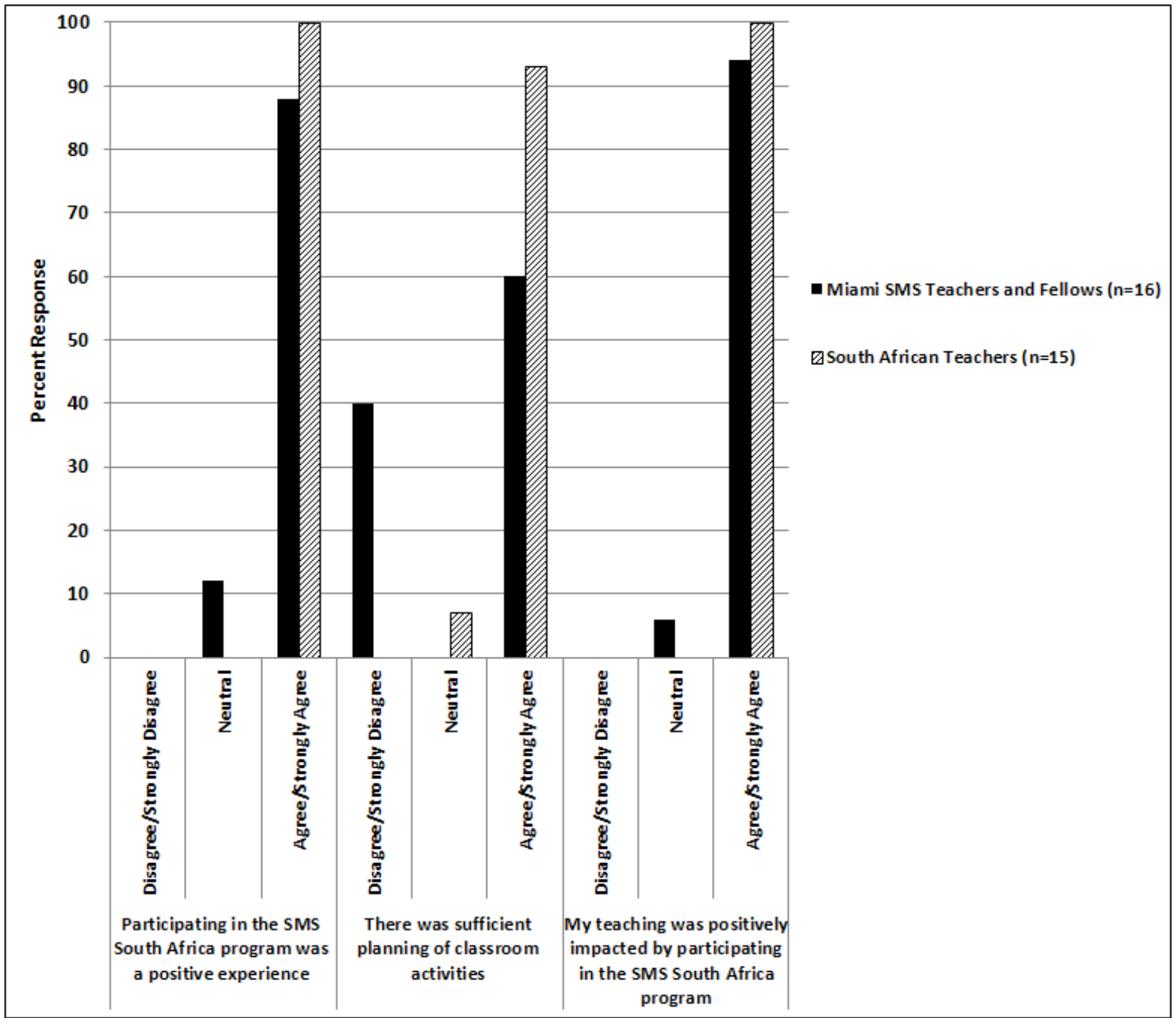

Figure 1. Evaluation responses of Miami science teachers, University of Miami postgraduate fellows, and South African teachers who participated in the Science Made Sensible program in South Africa 2009-2011 


\section{Science Cafés}

\subsection{Science Cafés in South Africa}

The Science Cafés draw inspiration from the world-wide movement of Café Scientifique (cafescientifique.org/) in which a scientist discusses a topic of current interest in his or her area of expertise with an audience in an informal setting (Dallas, 2006). Our version of Café Scientifique has three criteria to suit the South African context, based on our experience with some of the challenges faced by young people in South Africa. First, we focus on 'Youth Cafés' where the audience consists mainly of young people, many (but not all) of whom are still in high school. These are similar to the Junior Café Scientifique as described by Dallas (2006). Secondly, the café is held in a township so that participants do not have to travel far, and therefore spend time and money in order to attend. It is likely, although not documented, that black South Africans find it difficult to attend museums and other sites of informal learning as most such sites are situated in the formerly 'white' suburbs, some distance from the townships. Thirdly, we aim to invite mainly black scientists with whom the participants can identify as a 'role model'. Research has shown that although there are positive attitudes towards science amongst black children (Pell \& Manganye, 2007), their self-confidence and self-esteem in the science arena is relatively low (Dlamini, 2002). Topics presented by scientists have ranged from copper extraction to recycling, and the science of sport to biotechnology.

To what extent are the SCs successful in what they aspire to do? There is some debate in the literature regarding the role of such events. In a discussion of public communication of science (not necessarily for youth), Trench (2008) discusses a perceived shift from deficit models to dialogue models over the past decade. In the deficit model (which has been subject to considerable criticism), the audience is assumed to be "deficient in awareness and understanding" (p. 131), whereas the dialogue model is more of a conversation between 'equals': the scientists and the public. Trench, however, proposes that the shift from a discredited deficit model to the more acceptable dialogue model is not a true reflection of the current state of science communication. He maintains that the deficit model is still in currency, albeit in adapted forms, and that the dialogue model is a simplistic representation of a more complex reality of science communication forums. We welcome the views of Trench and others, such as Sturgis and Allum (2004), who argue that the deficit model should not be rejected. When a scientist presents a topic to a group of young people it is very likely that they are there to learn, so a version of the deficit model is highly relevant in the SCs we run in South Africa. This is not to say there should not be any dialogue - it is encouraged and welcomed - but to expect a relatively immature audience to engage in robust debate with a scientist on a topic they are just learning about (maybe for the first time) is not feasible.

Several of the SCs have been evaluated and typical evaluations are shown in Figures 2 and 3. The vast majority of the participants found the topic interesting, the speaker good, and the talk and discussion enjoyable. Very few negative comments were elicited. Suggestions for improving the cafés included making participants more active and having concrete 'props' rather than just being talk and discussion. Numerous future topics for cafés were suggested 


\section{Macrothink}

by the participants in the evaluation, enabling the organizers to have insights into topics of interest for township youth.

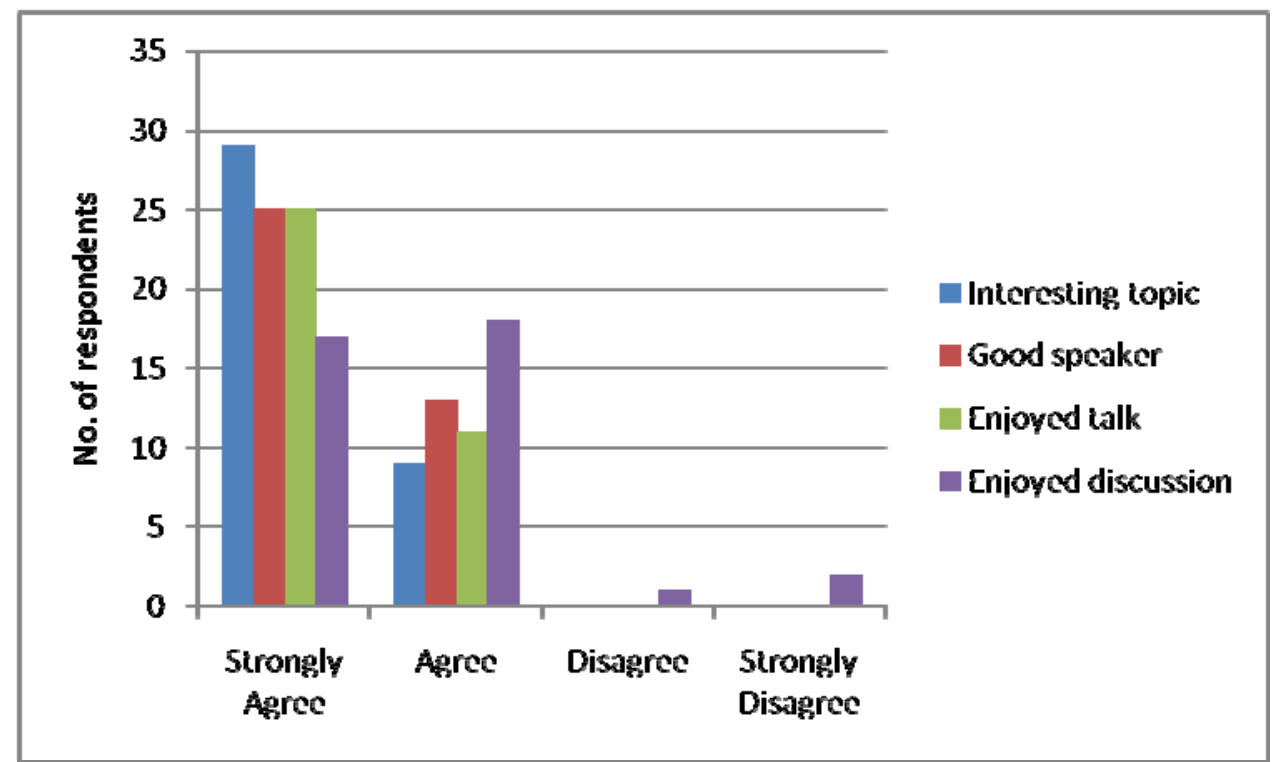

Figure 2. Evaluation of the Climate Change Youth Science Café $(n=38)$

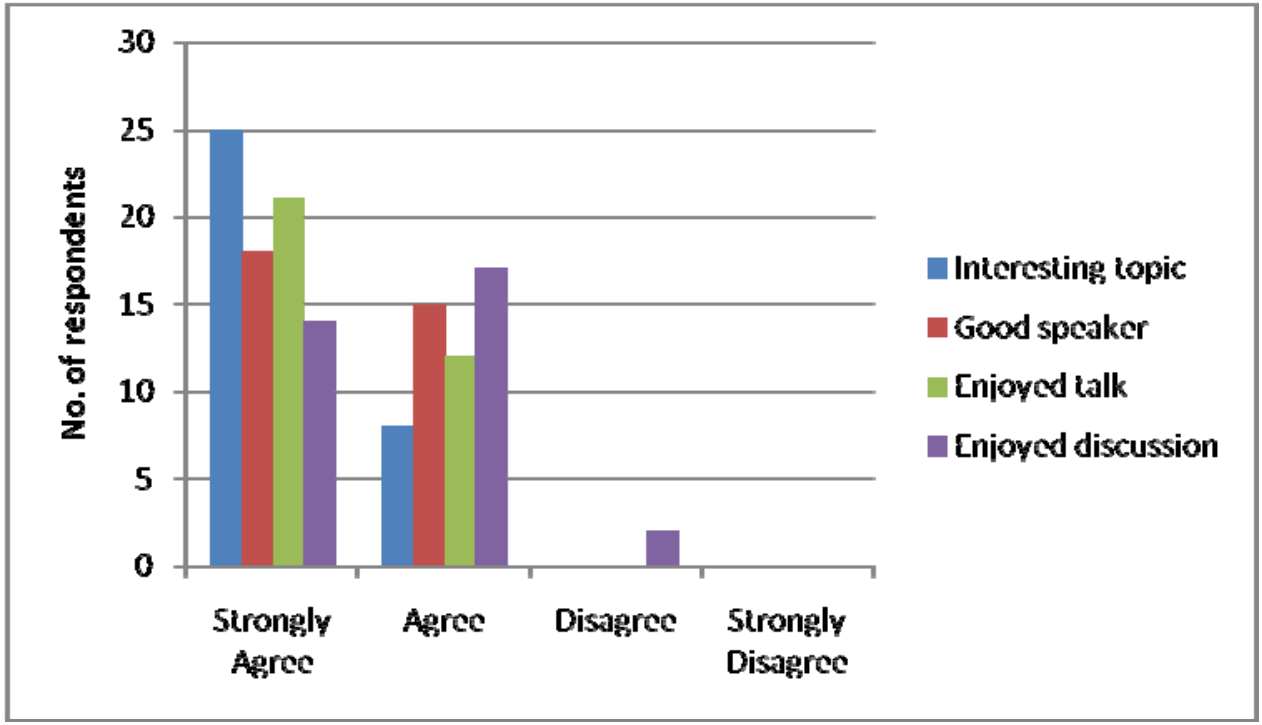

Figure 3. Evaluation of the Biotechnology Youth Science Café $(n=33)$

\section{Science Made Sensible and Science Cafés}

Relatively few programs have been reported that combine formal and informal learning. Hofstein and Rosenfeld (1996) argued that formal and informal learning experiences should be integrated in order to enrich students' range of learning opportunities. Dori and Tal (2000) 
investigated a community-based approach to a mixed formal-informal Science-TechnologySociety curriculum, and found that participants improved assessment scores in project-based work. The collaborative activities were highly successful, if time-consuming.

The SMS and SC programs are connected in that the goals of SMS reinforce those of SC: SMS fellows learn to communicate their science knowledge to children in a classroom setting, while SCs are about scientists communicating science to a similar audience in an out-of-school environment. The two programs have been working in the Pretoria region, and both have links with the Scienza Discovery Center, a science center based at the University of Pretoria. In the Mamelodi township near Pretoria, SMS has been based in Zakhele Primary School while SC has been held at the Mae Jemison Reading Room (a library funded by the USA Embassy). Another commonality is that the SMS program, like SC, also promotes informal education by arranging student visits to zoos and museums. In 2009 and 2010, the SMS and SC collaborated in running a mini-symposium at the National Zoological Gardens of South Africa (NZG), Pretoria. Speakers from the NZG, Pretoria Girls High, University of South Africa, and University of the Witwatersrand presented on topics such as teaching life sciences, career development, making science sensible to teachers in rural areas, as well as recent international research with zoo visitors.

Elements of SMS can and should be applied to SC and vice versa. For example, SMS graduate fellows in South Florida can follow the SC model and further develop their communication skills by presenting their research to the public in non-classroom settings, such as coffee shops and parks. SC can incorporate the SMS model by expanding their pool of scientists; they can invite South African graduate students to the townships to discuss their research. The graduate students will get practice talking to informal audiences, and the youth will be better able to relate to these young scientists.

\section{Conclusion}

Lessons learnt from the two programs are tentative, but valuable for further development of science learning. First, science communication courses for graduate students are likely to assist them to share their research with the public. Instead of leaving such training until later in a scientist's career, it can be done using programs such as SMS. Secondly, both SMS and SC programs need to be sustainable and need to be valued by the university leaderships. Thirdly, the introduction of inquiry-based learning into science classrooms is not easy, and programs such as SMS need to be complemented by teacher in-service programs that focus on such approaches.

We currently are beginning research into the nature of scientist-participant interactions in 'dialogue events' (Lehr et al., 2007) such as the SCs, as well as the extent to which they involve learning. In addition to understanding SCs better, such research may help to improve formal science learning and the way in which 'current science topics' are approached in the science classroom. 


\section{Acknowledgement}

The research is financed by the National Science Foundation (grant no. DGE0638135).

\section{References}

Adler, J., \& Reed, Y. (Eds.). (2002). Challenges of teacher development: An investigation of take-up in South Africa. Pretoria: Van Schaik.

Coombs, P. A., \& Ahmed, M. (1974). Attacking rural poverty: How non-formal education can help. Baltimore: John Hopkins University Press.

Dallas, D. (2006). Café Scientifique Déjà Vu. Cell, 126(2), 227-229. http://dx.doi.org/10.1016/j.cell.2006.07.006

Dlamini, E. (2002, 28 July - 2 August 2002). Non-traditional careers for black children in South Africa. Paper presented at the 10th Symposium of the International Organization for Science and Technology Education, Brazil.

Dori, Y. J., \& Tal, R. T. (2000). Formal and Informal Collaborative Projects: Engaging in Industry with Environmental Awareness. Science Education, 84(1), 95-113. http://dx.doi.org/10.1002/(SICI)1098-237X(200001)84:1<95::AID-SCE7>3.0.CO;2-W

Falk, J. H., \& Dierking, L. D. (2000). Learning from museums: Visitor experiences and their making of meaning. Walnut Creek, CA: Altamira Press.

Falk, J. H., \& Dierking, L. D. (2001). Learning from Science Centers: A Broader Perspective. ASTC Dimension, Jan/Feb, 4-7.

Frempong, G., Reddy, V., \& Kanjee, A. (2011). Exploring Equity and Quality Education in South Africa Using Multilevel Models. Compare, 41(6), 819-835. http://dx.doi.org/10.1080/03057925.2011.607488

Gallant, D. J. (nd). Science, Technology, Engineering, and Mathematics (STEM) Education: McGraw-Hill Education. Retrieved from https://www.mheonline.com/glencoemath/pdf/stem_education.pdf

Hofstein, A., \& Rosenfeld, S. (1996). Bridging the Gap between Formal and Informal Science Learning. Studies in Science Education, 28, 87-112. http://dx.doi.org/10.1080/03057269608560085

Kesidou, S., \& Roseman, J. E. (2002). How Well Do Middle School Science Programs Measure Up? Findings from Project 2061's Curriculum Review. Journal of Research in Science Teaching, 39(6), 522-549. http://dx.doi.org/10.1002/tea.10035

Lehr, J. L., McCallie, E., Davies, S. R., Caron, B. R., Gammon, B., \& Duensing, S. (2007). The Value of "Dialogue Events" as Sites of Learning: An Exploration of Research and Evaluation Frameworks. International Journal of Science Education, 29(12), 1467-1487. http://dx.doi.org/10.1080/09500690701494092 


\section{Macrothink}

McCallie, E., Simonsson, E., Gammon, B., Nilsson, K., Lehr, J., \& Davies, S. (2007). Learning to Generate Dialogue - Theory, Practice, and Evaluation. Museums and Social Issues, 2(2), 165-184.

National Research Council. (2011). Successful K-12 STEM education: Identifying effective approaches in science, technology, engineering, and mathematics.Committee on Highly Successful Science Programs for K-12 Science Education. Board on Science Education and Board on Testing and Assessment, Division of Behavioral and Social Sciences and Education. Washington, DC: The National Academies Press.

Pell, A. W., \& Manganye, H. T. (2007). South African Primary Children's Attitudes to Science. Evaluation \& Research in Education, 20(3), 121-143. http://dx.doi.org/10.2167/eri403.0

Sturgis, P., \& Allum, N. (2004). Science in Society: Re-Evaluating the Deficit Model of Public Attitudes. Public Understanding of Science, 13(1), 55-74. http://dx.doi.org/10.1177/0963662504042690

Trench, B. (2008). Towards an analytical framework of science communication models. In D. Cheng, M. Claessens, T. Gascoigne, J. Metcalfe, B. Schiele \& S. Shi (Eds.), Communicating science in social contexts (pp. 119-135): Springer. http://dx.doi.org/10.1007/978-1-4020-8598-7_7

\section{Copyright Disclaimer}

Copyright reserved by the author(s).

This article is an open-access article distributed under the terms and conditions of the Creative Commons Attribution license (http://creativecommons.org/licenses/by/3.0/). 